Article

\title{
Ageing in Suburban Neighbourhoods: Planning, Densities and Place Assessment
}

\author{
Byron loannou \\ Department of Architecture, School of Engineering, Frederick University, 1036 Nicosia, Cyprus; \\ E-Mail: b.ioannou@frederick.ac.cy
}

Submitted: 10 December 2018 | Accepted: 25 February 2019 | Published: 18 June 2019

\begin{abstract}
The article examines the environmental qualities perceived by ageing populations in suburban low-density and car-oriented neighbourhoods in comparison to more dense and central areas. The study focuses on Nicosia, Cyprus, a city that suffers from extended sprawl and car dependency in almost every urban district. The aim of the article is to investigate how older adults perceive and evaluate their place of residence and if this assessment relates to the suburban or the city centre profile of their neighbourhoods. For this reason, the study takes five residential districts, two central and three suburban areas, as case studies. Each of the selected residential districts performs differently in terms of percentage of the population over the age of 65; scale and street layout; adequacy in supporting land uses; building density; distance from the city centre and public space availability and condition. The almost exclusive use of private cars, as the main transportation mode is a common feature of all older adults interviewed in these areas. The older adults' perceptions of place are assessed through the Place Standard (PS), a simple recently awarded framework which structures conversations about place in regard to its physical elements as well as its social composition. PS is used as an interview tool, which allows the mapping/visualization of qualitative data. Qualitative in-depth interviews conclude to an evaluation of fourteen aspects that outline a residential district profile from mobility to green and urban image attractiveness, and from facilities to social contact and safety, covering almost every aspect of daily life. The article concludes that the neighbourhood assessment from older residents varies depending on the nature of the suburban neighbourhood. Density, layout and distance from the city centre matter according to the participants' evaluation and there is a clear preference towards suburban low-density areas.
\end{abstract}

\section{Keywords}

ageing; place standard; liveable neighbourhood; suburban development; urban densities; urban sprawl

\section{Issue}

This article is part of the issue "The City, Aging and Urban Planning", edited by Matthias Drilling (University of Applied Sciences and Arts Northwestern Switzerland) and Fabian Neuhaus (University of Calgary, Canada).

(C) 2019 by the author; licensee Cogitatio (Lisbon, Portugal). This article is licensed under a Creative Commons Attribution 4.0 International License (CC BY).

\section{Introduction: Narratives of Quality Residential Areas for Older Adults}

The aim of the article is to discuss the place assessment of suburban and city centre residential areas in Cyprus from the point of view of their senior citizens. A main problem of urban development in Cyprus, an Island state of the Eastern Mediterranean, is the extended sprawl and low densities that characterise the majority of its developed areas (Savvides, 2018). Ageing and place appropriateness in suburban neighbourhoods is a particular as- pect of this issue that has never before been discussed in detail or researched. Built areas in Cyprus decline from several goals of the Habitat Program (United Nations, 2018), since serious gaps occur in providing accessible and sustainable mobility for all, better performance of cities in terms of their environmental impact, access to quality public spaces and improve integration between urban, suburban and rural space (Ioannou, 2016). Lowdensity suburban areas with increasing older adults' population are typical for all the four urban conurbations of the area controlled by the Republic of Cyprus at the 
south (Figure 1). Nicosia, the capital, is the largest of the four, around 240,000 inhabitants in 2001 (28\% of the total population) covering a total area of around $200 \mathrm{~km}^{2}$. City population is almost six times the 1960 population of 45,000 inhabitants. The average population older than 65 was at the time $18.45 \%, 22.8 \%$ for the country and 29.9\% the EU average (Eurostat, 2017).

The article starts with a review of planning and development processes which produced the suburban fringe during the past decades. It continues with the profiling of older adults regarding residential mobility, family ties and ownership, and recent trends and preferences in these fields. A mapping of Nicosia neighbourhoods follows as an attempt to outline the geographies of ageing population of the city in relation to densities of suburban district types. Then, the Place Standard ([PS], 2018) assessment tool is applied for five selected districts of different profiles. Finally, twenty-five in-depth qualitative interviews, five from each district, on the perception of older adults for their place of residence, provide a comparative evaluation on the fourteen quality indicators assessed through the PS tool.

The main hypothesis of the article is to comparatively investigate how the population over the age of 65 assesses its neighbourhood and what is the relation (if any) of this assessment to suburban spatial features such as density. In this context an outline emerges clarifying which are the narratives of quality residential areas for older adults in the case of the Nicosia suburbia. The article also aims at providing a general context and define a set of issues for further research on the spatial character of Cyprus cities, which is today missing from a critical planning debate.

Typical narratives of sustainable neighbourhoods for older adults (Hooper, Matthew, Foster, \& Giles-Corti,
2015), that means denser and more crowded residential areas, are not the case of the local suburban reality in Cyprus. There is a series of weaknesses in most of the urban areas (loannides, 2018) related with the loose structure of the suburban fringe and the low densities that cannot support a broad range of urban amenities and services, more specifically: local central amenity cores are weak or even absent, so access to neighbourhood centres on foot (up to 400 to $1600 \mathrm{~m}$ ) to a diversity of destinations is limited; access to public transport is not adequate because of the insufficiency of the provided services; the plot-by-plot neighbourhood development and patchy design layout discourages connectivity and viability of focal points; external through connections at the perimeter of a district are limited and cul de sacs are the common; shaded streets with tree canopy cover are rare despite the hot Mediterranean climate; housing diversity and development types are deficient in most of the areas, while affordable housing is rare and in crisis; public parklands, access to parks, parks surveillance and safety are again problematic.

Contrary to the weaknesses of the built environment as described above, the development of social relation seems more vivid (Minas, Mavrikiou, \& Jacobson, 2013). There are still strong and frequent relationships between members of social groups sharing similar identities or being part of wider families, which is a positive condition (Buffel et al., 2014a). There is a need to investigate further whether these relationships foster participation, involvement, a "sense of community", or a feeling of belonging to the local neighbourhood (Lachapelle, 2008).

The current research sets densities and city plan/layout as the main terrain of interest, were variables like interpersonal relationships, place attachment and community engagement, are tested. Social param-

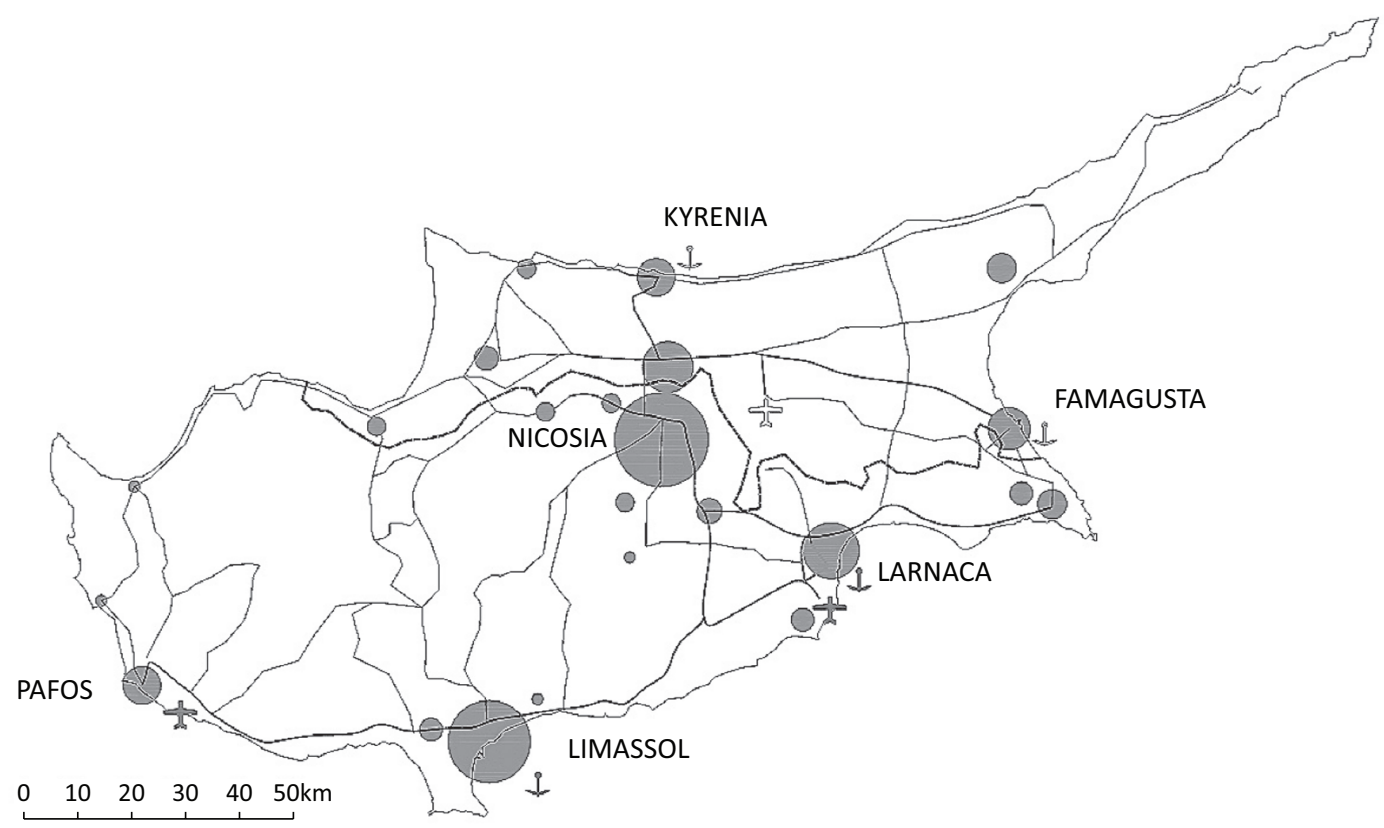

Figure 1. Map of Cyprus indicating Nicosia and the main settlements of the island. 
eters such as loneliness and low income, health condition, limited mobility, third age or other circumstances (Buffel et al., 2014b; Van Cauwenberg et al., 2014) are not included in the investigation hypotheses, in order to focus purely on the spatial dimension. The aim of the article is to examine how the majority of older adults assesses the place of their residence and if suburban residents perform differences in the perception of the quality of their place compared to central neighbourhood residents. This preliminary investigation does not include a number of other special social parameters equally important.

\section{Planning and the Production of the Current Suburbia}

Suburban development in Cyprus has gradually been developing during the last eighty years (Ioannou, 2016), and over the life span of the today's population over the age of 65. The current generation of ageing "suburbians", being in their youth then, was the first colonists of the early suburbs. Most of them have spent their whole lives at the residencies they were born and brought up since residential mobility in Mediterranean countries is relatively low (Arbaci \& Malheiros, 2010). Generally, suburban development is boosted by the growing dominance of the single-family detached home as a preferred lifestyle (Gammage, 2016). In fact, urbanisation occurred in Cyprus in the second half of the 20th century and, during the first stages, it was almost exclusively based on the typology of freestanding houses. In this context, the single-family detached home was not only a preferred lifestyle but also reflected a kind of middle class "appropriateness" (Ioannides, 2018). Even today, a big part of the society considers single house, as an evidence of descent living for a typical local family household, perceptions which are not only local. People in many countries see peripheral suburban places as locations where individuals ought to go to realize dreams of property ownership, access to nature, and community involvement (Lee, Hong, \& Park, 2017; Trudeau, 2018).

Suburbia has been associated with specific lifestyle, daily routines, mobility and consumption modes (Butler, 2005). Zoning is still a predominant planning tool in Cyprus despite the fact that it is an essentially negative mean of control, relying on a notional commitment to physical determinism (Butler, 2005). The bureaucratic rationality in planning, and the politics of satisfying social perceptions as well as the landowners' interests against "good" planning have established de-concentrated home ownership as the norm (loannou, 2016). Within this complete absence of public realm, other than roads, suburbanisation might completely diminish traditional spaces of encounter. The absence of neighbourhood masterplans and the fragmented layout development that serves only car circulation, as well as land speculation through the vast expansion of the development areas, was set as the rule since the 1950s (Morris, 1959). The layout design, by avoiding rectangular grids and us- ing dead ends, increases the length of automobile trip and at the same time discourages walking within the neighbourhood (Moudon et al., 2006). Extended development zones, not based on population forecasts, have left even the early suburban quarters to a large extent undeveloped, performing densities below 100 inhabitants/ha (Ioannou, 2016). For example, areas 1040, 1048 or 1075 (Figure 2) in Nicosia started to develop after the 1930s but they still contain empty plots around thirty to $40 \%$ of their total surface. The question is, how far is there an impact of these densities on the social relations and daily contacts of the older adults?

\section{Older Adults in Cyprus: Residential Mobility, Cultural Backgrounds and Changing Lifestyles}

"Ageing in place" has been an influential notion for social ageing policies in Europe since the 1990s (Ahn, 2017; Moulaert, Wanka, \& Drilling, 2017). It is important for ageing to evolve in a stable environment, equipped with the notion of home, family, and a strong collective memory of a neighbourhood past (Ahn, 2017). Several scholars have proven that traditional family bonds still active in Cyprus, while in a lot of cases relations and support of the older adults by their descendants are strong (Minas et al., 2013). At the same time due to the insufficient social infrastructure, combined with the unemployment and the reduction of the income of the younger generations, the older adults may support their children either economically or by providing daily services such as childcare or preparing meals. This frame of relations is usually spatially defined, since in many cases parents contribute by donating money or property in order for their children to settle down in a close distance (Minas et al., 2013). There are cases where parents move to a second house very close to their original one in order to pass it on to their children or, more commonly, cases where children are invited to build a new house as an extension of their parents' single house. There are also cases where empty plots close in proximity are donated to the children by their parents (Minas et al., 2013). Population over the age of 65 in Cyprus considers family bonds as a main reason to be happy and this is again a strong reason that shapes their relation to place locality (Neocleous \& Apostolou, 2016).

During the last quarter of the 20th century, the traditional role of the Mediterranean family in the support and daily care of its older adults is being subjected to economic, social and psychological strains, and has been in several cases seriously weakened (Phellas, 2013). The change in family values, the reduction in family size and the change of the traditional role of women have threatened the tradition of ageing in place and promoted the institutionalisation of the older adults (Troisi, 2013). There is justified evidence that in Cyprus the extent of these transitions is not yet widespread (Phellas, 2013).

The recent economic crisis that began in Cyprus in early 2010 has reduced pension benefits, thus having an 


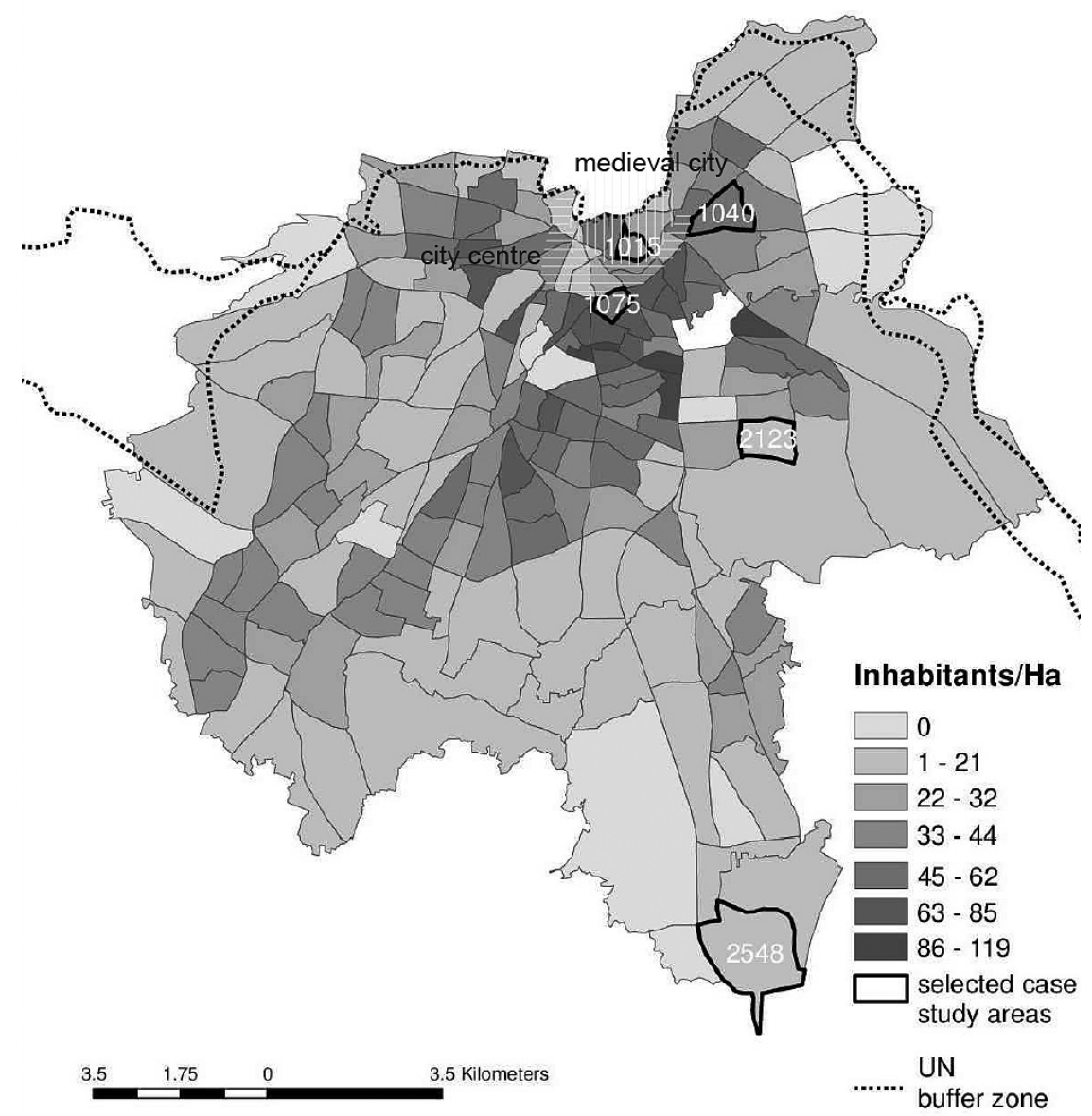

Figure 2. Nicosia postal districts density map. Medieval city: vertical white hatch; city centre: horizontal white hatch.

effect on housing options for the older adults, as well as on the capacity of their descendants to acquire their own home (Neocleous \& Apostolou, 2016). Due to these conditions many older adults have left care institutions and returned to their homes (Neocleous \& Apostolou, 2016), and in some cases cohabit with children or relatives. There are also government programs for nursing homes or home care (personal hygiene, house-cleaning, washing of clothes, shopping, etc.) that support older adults on their decision to live at home (Kouta, Kaite, Papadopoulos, \& Phellas, 2015). The employment of foreign domestic workers as live-in carers is another option that became very popular during the last decades (Panayiotopoulos, 2005). Both options support them to live in their own residences and avoid moving in with relatives, when the older adults need intensive care (Panayiotopoulos, 2005). This practice appears to be culturally acceptable and, indeed, laudable (Panayiotopoulos, 2005). In addition, this practice ensures in many cases that independent mobility in private vehicles lasts longer than the ability of the senior to drive since the car is there to be used by an assistant, if not by the older adults themselves (Neocleous \& Apostolou, 2016). All these changes have reversed the older trends of institutionalizing the older adults and brought society back to the traditional values of "ageing in place" (Neocleous \& Apostolou, 2016).

\section{Mapping Ageing in Suburban and Central Districts of Nicosia: Methodology and Basic Assumptions}

The case study analysis consists of two main steps. At first, there is a selection of five of 186 districts, based on differentiated density and spatial typology, in order to examine the main research hypothesis of how far environmental characteristics impact on the sense of satisfaction with lifestyle parameters. The second step concentrates on the selection of five key participants (older adults over the age of 65) from each district (twenty-five in total) for qualitative in-depth interviews based on the PS tool. The PS (2018) is a web application that provides an interview framework for a holistic place assessment.

Despite the fact that low urban densities are some of the most significant problems of the urban areas in Cyprus (DTPH, 2011), there is a lack of published survey data around the issue. The national Statistical Service censuses publish population data down to the level of a postal code district, which is the lowest spatial unit that data can be retrieved; moreover, available statistics on housing conditions are not place specific (Eurostat, 2014). This article analyses data at the level of a postal code district, which is not actually a neighbourhood or an administrative boundary, but it is an area more or less close to a walkable spatial entity (dimensions vary from $500 \mathrm{~m}$ to $2 \mathrm{~km}$ ). The research examines the density and 
the percentages of population over the age of 65 for 186 polygons (postal code districts) of a total population of 241,173 (census data from 2011). In around $75 \%$ of the 186 districts, the average population over the age of 65 varies between ten and $27 \%$, while a smaller number has significantly higher or lower percentages due to local specific conditions. The average density is around 45 inhabitants/ha while there is no obvious relation between the percentages of the population over the age of 65 and the densities in general. The density of the population over the age of 65 is a result of the historic evolution of each separate district and its specific development pattern.

In order to understand the ratio/scale of city expansion, only five districts in total are part of the walled old city that existed as the only built area prior to 1930 (Figure 2). All the other districts are mid- and late20th century suburbia, while only ten of them partly include ex-village cores which over time were intergraded into the city plan. The city was expanding concentrically around the walled city until the military events of 19631964 and the Turkish invasion of 1974, which led to the division of the island. From this point, onward Nicosia began to expand towards the south and southwest directions (Ioannides, 2018). Early suburbs are closer to the walled city and their population over the age of 65 has more or less settled there since its birth or early youth. The southern suburbs were more recently developed and their population over 65 immigrated there at a later stage of their lives.

In this context, the study selects five districts in order to cover areas of different densities and development phases of the city, as well as different layouts and built environment typologies. Table 1 indicates the profile of each area regarding its density (inhabitants/ha), population, percentage of older adults, distance from the city centre, public space availability and condition, walkability and public transport. Table 2 presents each district layout.

The main aim of the article is to investigate how the older adults of each district assess their neighbourhood and what is the relation (if any) of this assessment with spatial features and particular characteristics of place (Tables 1 and 2). The PS tool provides the context to examine this condition through face-to-face qualitative indepth interviews (Magaldi \& Berler, 2018).

Table 1. Basic features of the selected case study areas.

\begin{tabular}{|c|c|c|c|c|c|c|c|}
\hline Area & $\begin{array}{l}\text { Density } \\
\text { (inh/ha) }\end{array}$ & Population & $\begin{array}{l}\text { Percentage } \\
\text { of population } \\
\text { over the age } \\
\text { of } 65\end{array}$ & $\begin{array}{l}\text { Distance } \\
\text { from the } \\
\text { city } \\
\text { centre }\end{array}$ & $\begin{array}{l}\text { Public space } \\
\text { availability } \\
\text { and condition }\end{array}$ & Walkability & $\begin{array}{l}\text { Public } \\
\text { transport }\end{array}$ \\
\hline $\begin{array}{l}1015 \text { Agios } \\
\text { Antonios } \\
\text { walled city } \\
\text { district }\end{array}$ & 44 & 836 & $14 \%$ & $0 \mathrm{~km}$ & $\begin{array}{l}\text { Extended public } \\
\text { space (includes } \\
\text { medieval moat } \\
\text { park). Modest } \\
\text { condition }\end{array}$ & $\begin{array}{l}\text { Increased traffic } \\
\text { and on street } \\
\text { parking. } \\
\text { Limited } \\
\text { pavements }\end{array}$ & $\begin{array}{l}\text { In walking } \\
\text { distance } \\
\text { from the } \\
\text { central } \\
\text { bus station. }\end{array}$ \\
\hline $\begin{array}{l}1040 \\
\text { Pallouriotissa } \\
\text { core and } \\
\text { early suburb }\end{array}$ & 57 & 2980 & $21 \%$ & $1 \mathrm{~km}$ & $\begin{array}{l}\text { Limited public } \\
\text { spaces (include } \\
\text { a renovated } \\
\text { local square). } \\
\text { Good condition }\end{array}$ & $\begin{array}{l}\text { Car dominated } \\
\text { and unfriendly } \\
\text { local streets }\end{array}$ & $\begin{array}{l}\text { Two lines } \\
\text { to the city } \\
\text { centre, } 25 \\
\text { routes per } \\
\text { day each. }\end{array}$ \\
\hline $\begin{array}{l}1075 \text { Agios } \\
\text { Spyridonas } \\
\text { city centre }\end{array}$ & 52 & 188 & $17 \%$ & $0 \mathrm{~km}$ & $\begin{array}{l}\text { No significant } \\
\text { public spaces. }\end{array}$ & $\begin{array}{l}\text { Increased traffic } \\
\text { and on street } \\
\text { parking. } \\
\text { Limited } \\
\text { pavements }\end{array}$ & $\begin{array}{l}\text { In walking } \\
\text { distance } \\
\text { from the } \\
\text { central } \\
\text { bus station. }\end{array}$ \\
\hline $\begin{array}{l}2123 \\
\text { Aglantzia } \\
\text { suburb }\end{array}$ & 18 & 991 & $23 \%$ & $6 \mathrm{~km}$ & $\begin{array}{l}\text { An extended } \\
\text { and good } \\
\text { quality national } \\
\text { forest park at its } \\
\text { southern edge. }\end{array}$ & $\begin{array}{l}\text { Low traffic, } \\
\text { walkable } \\
\text { streets. }\end{array}$ & $\begin{array}{l}\text { One line, } \\
25 \text { routes } \\
\text { per day }\end{array}$ \\
\hline $\begin{array}{l}2548 \\
\text { Kallithea } \\
\text { Dali }\end{array}$ & 10 & 1950 & $5 \%$ & $13 \mathrm{~km}$ & $\begin{array}{l}\text { Fragmented } \\
\text { pocket parks } \\
\text { well equipped } \\
\text { especially for } \\
\text { kids, but with } \\
\text { limited green. }\end{array}$ & $\begin{array}{l}\text { Low traffic, } \\
\text { walkable } \\
\text { streets. }\end{array}$ & $\begin{array}{l}\text { One line, } \\
30 \text { routes } \\
\text { per day }\end{array}$ \\
\hline
\end{tabular}


Table 2. Brief description and layout of each district.

Area

Typical fabric segment from Google Earth

Layout

1015: Agios Antonios is a terraced medieval fabric, city centre quarter of mixed land uses (retail, workshops and recreation). It also hosts a relatively high percentage of economic immigrants (Statistical Service, 2011).
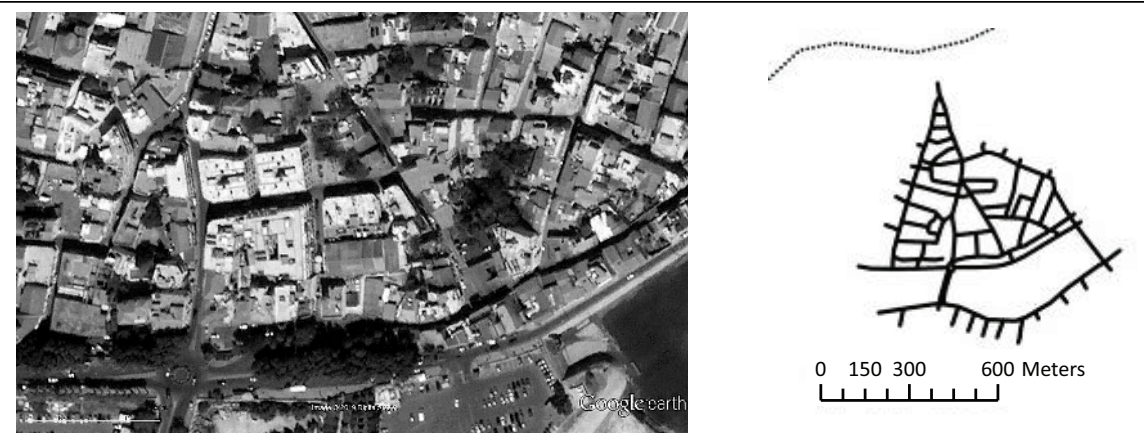

$0 \quad 150300 \quad 600$ Meters

1040: Pallouriotissa is an old terraced core combined with an early suburb part of single, semi-detached houses and flat buildings. It is mainly a residential quarter with boundary high streets functioning as neighbourhood centres. It also hosts an increasing percentage of economic immigrants (Statistical Service, 2011).
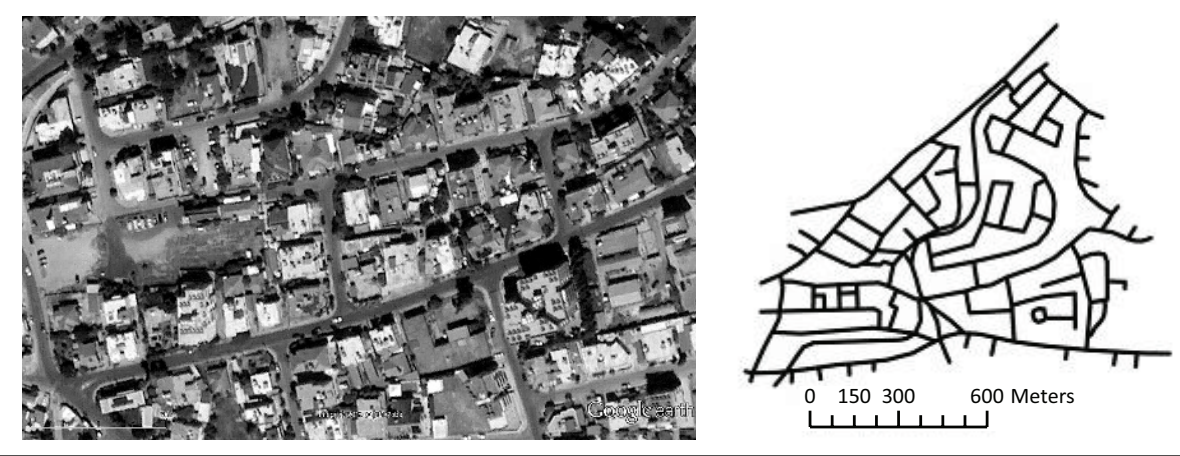

1075: Agios Spyridonas was initially an upper-class early suburb, but today it has completely transformed into downtown quarter mainly with flat and office buildings. It has a high extent of mixed land uses (offices, retail and recreation).

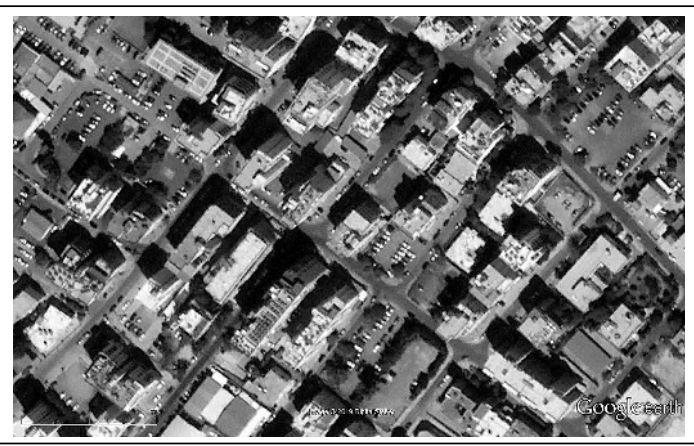

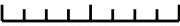
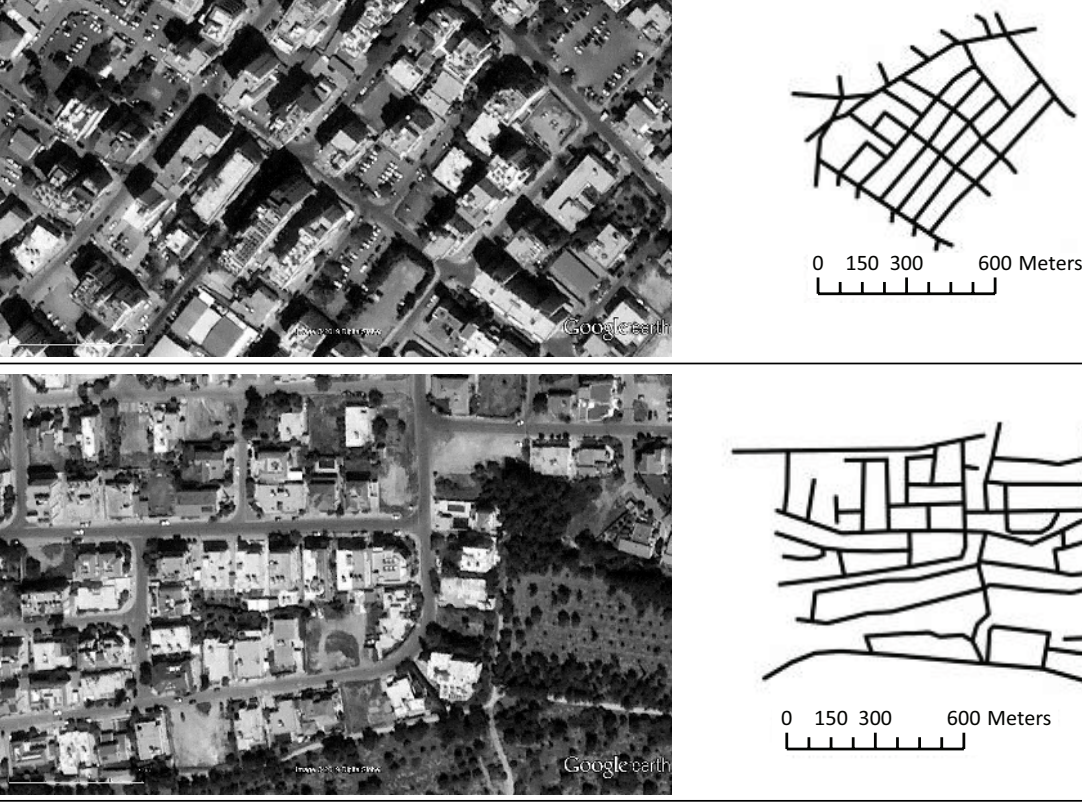
$0 \quad 150300$

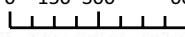

2123: Aglantzia is a late 20th century suburb, mainly of single freestanding houses and small-scale family flat buildings. It is a dominantly residential area attached to the larger national forest park of the city.

2548: Kallithea is a new 21st century suburb at the city fringe, mainly of single freestanding houses. It is a purely residential area with an incomplete patchy layout.
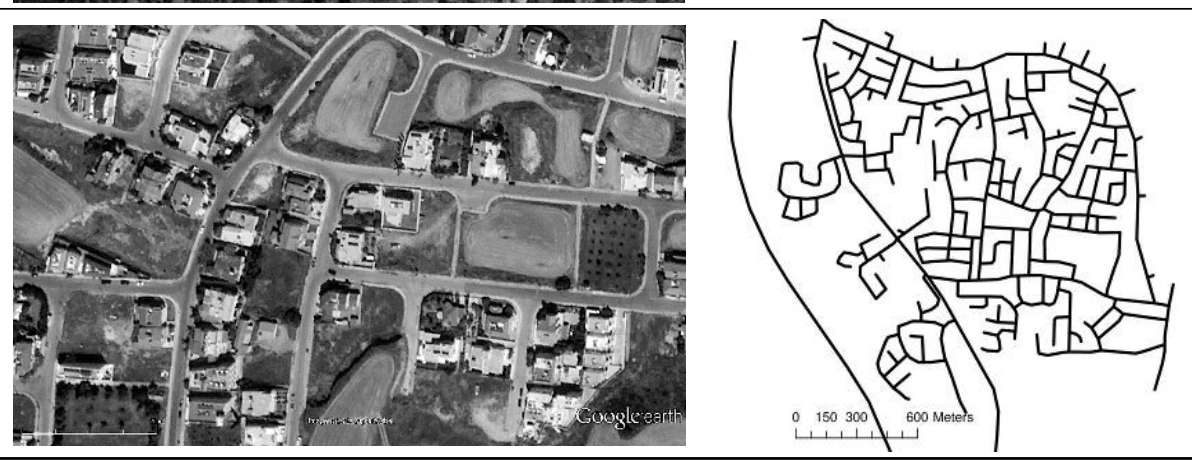
Each interview took place in the older adults' own home lasted about one hour and it was recorded. Interviewees did not receive any printed or electronic material; PS was just scheduling and supporting the conversation. The content and the structure of the interview followed the analytic fourteen points of PS tool format, summarised in the following questions (PS, 2018):

1. Moving around (ma): Can I easily walk and cycle around using good-quality routes?

2. Public Transport (pt): Does public transport meet my needs?

3. Traffic and parking (tp): Do traffic and parking arrangements allow people to move around safely and meet the community's needs?

4. Streets and spaces (sp): Do buildings, streets and public spaces create an attractive place that is easy to get around?

5. Natural space (ns): Can I regularly experience goodquality natural space?

6. Play and recreation (pr): Can I access a range of space with opportunities for play and recreation?

7. Facilities and amenities (fa): Do facilities and amenities meet my needs?

8. Work and local economy ( $w \mathrm{l})$ : Is there an active local economy and the opportunity to access goodquality work?

9. Housing and community (hc): Do the homes in my area support the needs of the community?

10. Social contact (sc): Is there a range of spaces and opportunities to meet people?

11. Identity and belonging (id): Does this place have a positive identity, and do I feel I belong?

12. Felling safe $(\mathrm{fs})$ : Do I feel safe here?

13. Care and maintenance $(\mathrm{cm})$ : Are buildings and spaces well cared for?

14. Influence and control (if): Do I feel able to take part in decisions and help change things for the better?

Each of the above questions included 5 to 6 clarification questions. In the end of the discussion of each one of the fourteen discussions, the interviewee had to give its place a score from 1 to 7 .

PS is suitable not only for older adults, but for any age group, so the results of the article could be easily benchmarked against further intergenerational investigations, especially in relation to the same neighbourhoods. Although PS themes could be seen as an expanded and more detailed version of the Eight Domains of Age-Friendliness (Plouffe, Kalache, \& Voelker, 2016). The current research adopts PS because of its applicability, and because as a very recent product it encompasses all the up-to-date virtues and principles for a sustainable place globally (Farr, 2011; Healy, 2010). PS facilitates a structure for conversations about place in a simple and understandable way. It encourages the interviewee to think about the physical elements of a place (for example, its open spaces, buildings, and mobility options) and at the same time the social aspects, such as whether people feel they get care or they have influence and sense of control (Hasler, 2018). By translating the brief into the Greek language and, at the same time, knowing the profile of the interviewees of the Nicosia neighbourhoods, the PS tool been adapted to the place. Furthermore, it provided prompts for discussions and sets the elements of a place in a methodical way, being in this way open and flexible.

In order to select the key participants interviewers did a preliminary visit to each district, talking with residents from house to house covering all local streets and creating wider list of twenty potential interviewees per district. The group of older adults between 65 and 80 years, of Cypriot origin, car drivers and homeowners was the predominant sample, exceeding $70 \%$ of the total in every district. Excluding the "old old" group (80+; McCracken \& Philips, 2005) and focusing on Cypriot origin, car drivers and homeowners, it neglects a number of cases that might need a special investigation. On the other hand, it covers the majority of older adults in Nicosia. From the twenty potential interviewees, five were selected in order to represent both males and females and have a good spatial distribution in the district.

For findings' validation purposes, five pilot test interviews were conducted initially from the district that was well known from previous research: 1040. According to the findings a number of clarification questions from the in-depth interview guide were modified to adapt the local reality.

\section{Results and Discussion}

The description of the results follows the points of the spider diagrams of Figure 3, clockwise.

Moving around (ma), walk and cycle has strangely revealed as a paradox in respect to what would normally be expected (Zeitler, Buys, Aird, \& Miller, 2012). Denser areas have lower scores, because even the denser districts selected are not walkable or sufficient in covering the majority of the daily needs of a resident, while non-car owners are actually segregated (Savvides, 2018). The score for the city centre and walled city quarters is the lowest, mainly because of the narrow spaces given to pedestrians and the safety issues from the dense and illegal, in many cases on street parking. These quarters are fully car dominated not only because of the residents, but also because of their city centre uses that attract more traffic. In this context, the older adults find it hard to walk around and cycle. Suburban quarters score higher because due to the lack of density, there are less cars in the streets, traffic is low, especially during the morning and evening hours and more street space is provided for walking and cycling.

The elders' vision on public transport (pt) is in all case unexpected. This is because the general use of public transport in Cyprus is below 3\%, and because the interviewees are car owners and every day users that rarely 

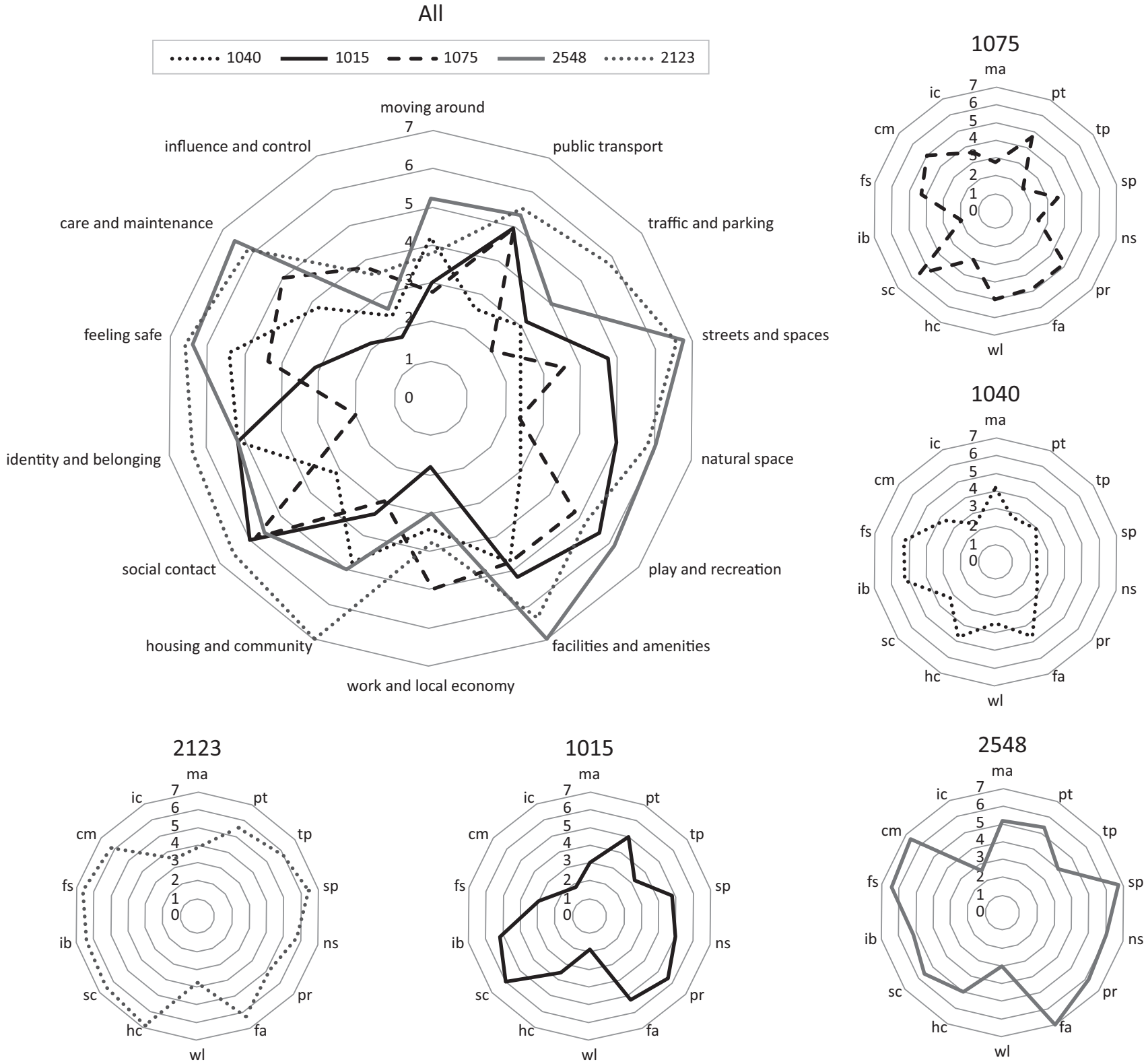

wl

Figure 3. PS marking graphs for the five case study districts.

use public transportation. Relatively high marking could be seen as an attempt of being polite about something they are not able to evaluate. On the other hand, it happens that central areas like 1015 and 1075 have better connections since they are in the city centre and bus routes are radial.

Traffic and parking (tp) are in almost every case an issue and again the score is proportional to density levels. Central areas are congested, while car drivers feel more facilitated in the suburban quarters, again proportional to density. This is a typical result aligned to literature findings, where mobility comes up as a dominant feature (Zeitler \& Buys, 2014).

Responses about the condition of streets and spaces (sp) are different for each district. The lowest score characterises the early suburbia (1040), that when developed there was no concern at all with the provision of neigh- bourhood public spaces. The renewal of the main streets of the old core and the construction of a new public square during the last decade has not succeeded to attract the presence and the esteem of the older adults. The central quarters gave an average score in reference to streets and open spaces, besides the fact that they are both benefit from the proximity of big open spaces and this might happen because their internal street network does not support walkability. Older adults from recently developed districts give higher scores to their streets and open spaces because according to them they are not congested with cars and because lower densities allow access to "more open sky". This aspect is of high importance as indicated in other relevant research (Moudon et al., 2007). It is also important to see that that "walkability" is not a major concern and was not part of the participant's daily routine in contrast to many cases 
mentioned in relevant literature (for example, Van Holle et al., 2014).

Natural space (ns) explains the adequacy of public parks, greenery, trees, gardens and soft surfaces. As it might be expected, less dense and central areas indicate a better score. It is interesting that the early suburban district (1040) has the lowest score despite the fact that it includes green private gardens around the detached houses, similarly with the central area (1075) were private gardens are limited. Older adults do not consider just the visual aspects of green as enough of an advantage; they evaluate spaces of green that they can comfortably use. The walled city district (1015) performs better because of the moat (a continuous open space around the Venetian walls of the old city), with extended green spaces. It is unexpected though that late suburbia (2123) adjacent to a national forest park and new suburbia (2548) have the same score. There is maybe a feeling that new, very low-density suburbia creates a feeling of living outside the city in a kind of natu$\mathrm{ral} /$ rural environment.

Again, an unexpected score is the one concerning opportunities for play and recreation (pr). One would expect that in denser and more central districts, the score would be higher due to the increased numbers of cafés, gyms and other facilities where reality shows exactly the opposite. This research so far is unable to interpret this result; a further research is needed to clarify this point with a larger and more representative sample. One possible interpretation is that the typical recreation facilities in the centre of town are not attractive to this social group. Some typical, popular, weekly recreation options of older adults especially for the social group examined here are: dinner in local tavern; coffee at the neighbourhood coffee shop; excursions to the beach, forests the countryside, mountain villages or religious places; walking and hiking; social events at home with family and friends; watching sports games; hunting; religious ceremonies; etc. (Minas et al., 2013; Phellas, 2013). In those terms, the city centre is not considered a popular destination for recreation for the older adults' in Cyprus. The high score at the suburban districts reflects the proximity and accessibility of households to such popular recreation destinations. This kind of leisure and recreational activities play an important role for the older adults' life (Cho \& Yi, 2013).

The correlations are also the same regarding assessment of the facilities and amenities (fa). Central areas are still providing more shopping and service opportunities than suburbia, but the retail and services geography has vastly changed during the past years in favour of the suburbs. The most important change is the construction of peripheral malls and super stores/retail parks along peripheral high streets, which caused the shrinking of retail and services in the city centre, and along central commercial streets (Ioannou, 2016). It is normal in a car-oriented society and for a social group characterised by active car drivers to expect a higher level of satisfaction at the sub- urbia more than the city centre, since high mobility can overcome the limitations that residential, self-selection may impose (Cao, Mokhtarian, \& Handy, 2008). In any case, there is no typical or expected answer in how older adults of different abilities perceive amenities as shopping and services (Nyman et al., 2018).

The twenty-five in-depth qualitative interviews revealed that most of the pensioners do not work on a daily basis and they might not be interested to do so (wl). District 1075 (city centre) is an office district that hosts a big number of service-providers and enterprises, owned by or employ older adults, which it is why these districts perform the highest satisfaction rate in the field of work and local economy. On the other hand, it is not expected in an area of high proportion of workshops and traditional shops (which characterises area 1015 of the walled city) to perform with a lower score in terms of working opportunities. It seems that office professions or professionals better educated are indeed more willing to continue working after 65 .

The question about housing and the community (hc) intended to clarify the quality and offer of housing opportunities in the neighbourhood and their views on the quality of their own home. Does the quality of their residence reflect their opinion on their neighbourhood? The answers correspond to the age and the condition of houses in each district. The more recently developed areas with newer buildings obtain higher score. District 1075 (city centre) performs badly for two reasons; flats for rent or sale are limited since a number of owners prefer converting buildings into offices. Field observation has shown that a number of the flats are in bad condition because most of them have not been renovated. On the contrary there are dwellings in district 1040 (early suburb) and 1015 (walled city) that are older, but due to several planning policies they have been recently extensively renovated.

The discussion concerning social contacts (sc) investigated the opportunities and frequency of daily or weekly contact with other people. This issue gained the highest scores out of all the fourteen points, in all the investigated districts? This may be an indicator of a generalised solidarity and the strength of the notion of the family which relates to the traditional roots of the particular society. The regular use of private vehicles is perhaps one of the factors that facilitates mobility in every district, making proximity important as a factor for facilitating social contacts. The new suburban district (2548) has the highest score among others, despite the fact that it is a newly developed low-density area, where social networks are not consolidated in space compared to the older ones. A better performance may also occur because of particular conditions such as the fact that the older adults recently moved there in order to live near their children's and support them (or be supported by them). On the contrary, interviews with people of the central areas have revealed that most of their children have moved away and have started their own house- 
hold in more distant locations, reducing subsequently the frequency of contacts with their parents. This new trend for the cities of the Mediterranean region has to inform the typical patterns of residential mobility (Arbaci \& Malheiros, 2010).

The strength of identity and sense of belonging (ib), including the emotional bond with the place of residence, does not seem to be affected by how old each district is, or from of the duration of residency there. It is possible that the interviewees describe their affiliation with an imaginary, maybe wider district, and not the exact quarter referred to in this research. When participants talked about bonding with a place, they may have been referring to the whole city in a broader sense, as distinct urban functional areas as Nicosia have no legible boundaries across neighbourhoods (Savvides, 2018). In the case of district 1077 (city centre), which is actually a downtown commercial area and not a typical neighbourhood, the score is substantially lower. In this mixed-use city centre area, it is more difficult to build social relations locally. Meeting a neighbour even during a daily morning or afternoon walk, it is not as possible as in the purely residential areas.

The responses relating to the notion of safety (fs) relate with the centrality of the place but also with existence of mixed uses. Normally, the safety performance of downtown areas may vary in respect of the quality of public space (Loukaitou-Sideris \& Ehrenfeucht, 2009). At the same time more peripheral and quieter quarters are seen as safer, which is not in any case a rule characterising suburbia. Several interviewees feeling less safe suggested that economic immigrants and marginalised groups that live in central areas and mixed uses districts are the reason for their view. This response corresponds to a conservative stereotype of especially older generation Cypriots (Hadjipavlou, 2003). Nonetheless, it's still puzzling how a dark and empty neighbourhood/suburbian street makes them feel safer than a busy commercial road in the city centre. In some cases, safety is perhaps in an impression linked mostly to traffic; areas with less traffic in lowdensity suburbia makes them feel safer.

Impressions of how cared and maintained $(\mathrm{cm})$ the environment is have, again, to do with the building age, newly developed areas are performing better, since limited urban renewal projects exist to support older areas. Furthermore, central areas attract soft forms of vandalism, graffiti on walls, damages of street furniture, which is difficult to regularly repair. This kind of attitudes perhaps create stress for the older adults.

Influence and control (if) over there place of living, has to do with the role residents play in minor or major decisions affecting the urban form and structure. This question obtains the minimum score compared to all the other themes. This relates to a general issue characterising the Cyprus planning and development system that has not yet adopted strong public consultation processes, which can inform citizens about future projects, designs and planning decisions and convince citizens that have their views have been considered. (Ioannou, 2016). District 1075 (city centre) has a slightly better performance than the older and more central areas maybe because pilot renewal projects were implemented in the area. Interviewees in this quarter might have been professionally more active and thus involved in decision-making processes than residents of other city centre districts.

\section{Conclusions}

The results respond to the main hypothesis of the article indicating that the population over the age of 65 assesses its neighbourhood differently according to the spatial features such as density. Older adults in suburban districts are more satisfied than the same age group in most central districts.

Older adults' narratives for quality residential areas are favouring the suburban districts, which is a result of urban sprawl, rather than the group of compact city centre districts. This is not a positive result for the future of the sustainable urban development in Nicosia. In older adults' perception, higher density central areas lack in quality when reviewing twelve out of the fourteen assessed parameters, including streets and spaces, housing and community, care and maintenance, identity and belonging, traffic and parking, safe, as well as natural space compared to the same parameter in the suburban part of the sample. Central areas perform better as places of work and basis for local economy as well as places were residents can influence and control change compared to the suburban ones. Suburban districts are seen as better places to live for the older adults than the more central ones. Older adults find them also more appropriate for walking, something which is understood as an active exercise and not a necessary part of serving daily needs.

The results of the PS assessment confirm a finding that is not only relevant to the older adults but has more intergenerational and wider relevance. In general, suburban low-density neighbourhoods are highly appreciated and more positively accessed by their inhabitants than the central and denser areas (Gordon \& Cox, 2012). Older adults in Cyprus today have been at the core of the urbanisation era when they were young who moved to the promising new urban areas, leaving back their rural past. Living conditions at the urbanised areas of the 1960s to 1980 s were greatly improved compared to the amenities and daily life of the countryside and the rural villages. The standards of living in the country increased at a higher rate during the suburbanisation period compared to other EU countries (Orphanides \& Syrighas, 2012). For this reason, the stereotype of suburban car-depended daily life has deep roots in their minds as a lifestyle virtue.

Nevertheless, a more detailed review reveals that for a number of conditions, centrality and density issues do not play or play a minor role in their assessment as quality places. Social contacts for the group of older adults is more or less spatially deliberated due to the dominant use of private vehicles. The same applies to play 
and recreation, as well as work and the local economy, because they relate to the generic habits and the attitudes of daily life of the Cypriot older adults. On the other hand, suburban quarters are clearly preferred in terms of streets and spaces, natural space, facilities and amenities, feeling safety, care, and maintenance.

Finally, issues as influence and control need further clarification. Older adults' assessment of their neighbourhood prioritises the opportunities of social activity than the possibility of an active involvement to the decisions for the future of their place. Literature also underlines the impact of "local opportunity structures", such as mini markets and groceries, cafes and banks, which are clearly appreciated both as means of social participation and as opportunities of involvement (Buffel et al., 2014a). In our cases, it seems that there is no preference for these places to exist as part of the neighbourhood structure or as external destinations outside of them.

Marked divergence among districts in terms of their quality assessment is generally marginal. This is because actual differences in terms of density and layout among Nicosia quarters if compared to the diversity of other European or US cities are limited (Farr, 2011). With the exemption of the medieval walled city district (1015) all other four districts are products of the suburban boost of the second half of the 20th century (Ioannides, 2018). At the same time, the interviewees' social profile is almost the same.

It is clear that, for a number of reasons, older adults favour less the denser and central areas than the suburban and fridge areas. Residential mobility is limited for most with limited possibilities to leave a deprived district. At the same time, the attractiveness of the central areas for other social groups is also reduced. Limited residential mobility and ageing in place are fundamental elements for most of the residential areas in Cyprus (Minas et al., 2013). The current imbalance between centre and periphery may affect them. Encouraging people living in central city areas needs to be supported by more incentives and high value services in order older adults to feel as happy as their counterparts in the suburbs. Enhancing the quality of life in denser and central areas where the older adults people perceive as deprived will support and enable sustainable urban development and compacts city initiatives.

In parallel, planning concerns and investment in public projects have to increase their emphasis in favour of for central neighbourhoods in order to support equity and balanced urban development. Even in the cases of recent urban renewal projects in the city centre, these projects fail to integrate and have minor influence on its inhabitants' place satisfaction. Especially in the case of Cyprus, were the planning and real estate practice facilitates suburban expansion, planning has to support further the central and denser areas in terms of upgrading streets and spaces, providing natural space, creating more facilities and amenities, improving the safety notion and providing incentives for care and maintenance.
Enhancing age friendly districts in Cyprus will prevent urban districts from decay and secure diversity, and the liveability of all city quarters.

Within this frame, there is a need to compare further collected data and results in the same fields for more types of population groups and at the same selected areas. Furthermore, research around the spatial living conditions of older adults in Cyprus can be expanded to include different types of districts like rural or tourist areas and also more diverse social groups such as non-car owners, immigrants etc. Finally, the current approach can support further research on issues concerning the suburbia and the design of planning policies toward liveable denser central neighbourhoods.

\section{Acknowledgments}

I would like to thank Konstantinos Xenofondos and Marilia Yiallourou, Frederick University graduates, for their support in interviewing elders from the neighbourhoods of Nicosia. Special thanks to my colleague Lora Nicolaou for the decisive input and her creative remarks.

\section{Conflict of Interests}

The author declares no conflict of interests.

\section{References}

Ahn, M. (2017). Introduction to special issue: Aging in place. Housing and Society, 44, 1-2.

Arbaci, S., \& Malheiros, J. (2010). De-segregation, peripheralisation and the social exclusion of immigrants: Southern European cities in the 1990s. Journal of Ethnic and Migration Studies, 36(2), 227-255.

Buffel, T., De Donder, L., Phillipson, C., Dury, S., De Witte, N., \& Verté, D. (2014a). Social participation among older adults living in medium-sized cities in Belgium: The role of neighbourhood perceptions. Health Promotion International, 29(4), 655-668.

Buffel, T., McGarry, P., Phillipson, C., De Donder, L., Dury, S., De Witte, N., ... Verté, D. (2014b). Developing agefriendly cities: Case studies from Brussels and Manchester and implications for policy and practice. Journal of Aging \& Social Policy, 26(1/2), 52-72.

Butler, C. (2005). Reading the production of suburbia in post-war Australia. Law Text Culture, 9, 11-33.

Cao, J., Mokhtarian, P. L., \& Handy, S. L. (2008). Examining the impacts of residential self-selection on travel behavior: A focus on methodologies. Transportation Research, 29(3), 359-395.

Cho, G., \& Yi, E. (2013). Analysis on leisure patterns of the pre-elderly adults. Journal of Exercise Rehabilitation, 9(4), 438-445.

DTPH. (2011). Nicosia local plan. Nicosia: Ministry of Interior, Department of Town Planning and Housing.

Eurostat. (2014). Housing conditions. EC Europa. Retrieved from http://ec.europa.eu/eurostat/ 
statistics-explained/index.php/Housing_conditions

Eurostat. (2017). Population age structure indicators. EC Europa. Retrieved from https://ec.europa.eu/ eurostat/statistics-explained/index.php?title=File: Population_age_structure_indicators,_1_January_ 2017_(\%25).png

Farr, D. (2011). Sustainable urbanism: Urban design with nature. Boston, MA: Wiley.

Gammage, G. (2016). The future of the suburban city. Washington, DC: Island.

Gordon, P., \& Cox, W. (2012). Cities in western Europe and the United States: Do policy differences matter? Annals of Regional Science, 48, 565-594.

Hadjipavlou, M. (2003). Inter-ethnic stereotypes, neighbourliness, and separation paradoxes and challenges in Cyprus. Journal of Mediterranean Studies, 13(2), 281-318.

Hasler, K. (2018). Place standard: A practical tool to support the creation of healthier places. European Journal of Public Health, 28(4), 12.

Healy, P. (2010). Making better places: The planning project in the twenty-first century. Basingstoke: Palgrave MacMillan.

Hooper, P., Matthew, K., Foster, S., \& Giles-Corti, B. (2015). The building blocks of a 'liveable neighbourhood': Identifying the key performance indicators for walking of an operational planning policy in Perth, Western Australia. Health \& Place, 36, 173-183.

loannides, K. (2018). A brief review of the evolution of planning in Cyprus from the end of the World War II to the present. In N. Patsavos \& J. Pissourios (Eds.), The Cypriot city paradigm. Urbanity issues in design and planning (pp. 49-74). Athens: Domes.

loannou, B. (2016). Post-colonial urban development and planning in Cyprus: Shifting visions and realities of early suburbia. Urban Planning, 1(4), 79-88.

Kouta, C., Kaite, C., Papadopoulos, I., \& Phellas, C. (2015). Evaluation of home care nursing for older adults people in Cyprus. International Journal of Caring Sciences, 8(2), 376-384.

Lachapelle, P. (2008). A sense of ownership in community development: Understanding the potential for participation in community planning efforts. Community Development, 39(2), 52-59.

Lee, J., Hong, S., \& Park., Y. (2017). Predictable surprise: The spatial and social morphology of aging suburbs in the U.S. metropolitan areas. Sustainability, 9, 458.

Loukaitou-Sideris, A., \& Ehrenfeucht, R. (2009). Sidewalks. Conflict and negotiation over public space. London: MIT.

Magaldi, D., \& Berler, M. (2018). Semi-structured Interviews. In V. Zeigler-Hill \& T. Shackelford (Eds.), Encyclopedia of personality and individual differences ( $\mathrm{pp}$. 1-16). Cham: Springer.

McCracken, K., \& Philips, D. (2005). International demographic transitions. In G. Andrews \& D. Philips (Eds.), Ageing and place. Perspectives, policy, practice (pp. 36-60). Oxon: Routledge.
Minas, C., Mavrikiou, P., \& Jacobson, D. (2013). Homeownership, family and the gift effect: The case of Cyprus. Journal of Housing and the Built Environment, 28, 1-15.

Morris, W. (1959). Planning report. Nicosia: Department of Town Planning and Housing.

Moudon, A., Lee, C., Cheadle, A., Garvin, C., Johnson, D., Schmid, T., .. . Lin, L. (2006). Operational definitions of walkable neighborhood: Theoretical and empirical insights. Journal of Physical Activity and Health, 3(1), 99-117.

Moudon, A., Lee, C., Cheadle, A., Garvin, C., Johnson, D., Schmid, T., \& Weather, R. (2007). Attributes of environments supporting walking. American Journal of Health Promotion, 21(5), 448-459.

Moulaert, T., Wanka, A., \& Drilling, M. (2017). Mapping the relations between age, space, and exclusion. Oslo: Rosenet COST Action.

Neocleous, G., \& Apostolou, M. (2016). Happiness in and out of nursing homes: The case of Cyprus. International Social Work, 59(4), 533-544.

Nyman, S., Barker, A., Haines, T., Horton, K., Musselwhite, C., Peeters, G., ... Wolf, J. (2018). The Palgrave handbook of ageing and physical activity promotion. London: Palgrave Macmillan.

Orphanides, A., \& Syrighas, G. (2012). The Cyprus economy. Historical review, prospects, challenges. Nicosia: Central Bank of Cyprus.

Panayiotopoulos, P. (2005). The globalisation of care: Filipina domestic workers and care for the older adults in Cyprus. Capital \& Class, 29(2), 99-134.

Phellas, C. (2013). Quality of life and older people: An empirical study amongst older Cypriots. In C. Phellas (Ed.), Aging in European societies. Healthy aging in Europe (pp. 221-236). New York, NY: Springer.

Place Standard. (2018). Place standard: How good is our place? Place Standard. Retrieved from https:// placestandard.scot/\#/home

Plouffe, L., Kalache, A., Voelcker, I. (2016). A critical review of the WHO age-friendly cities methodology and its implementation. In S. Garon \& T. Moulaert (Ed.), Age-Friendly Cities and Communities in International Comparison (pp. 19-36). Basel: Springer.

Savvides, A. (2018). Housing and transit integration prospects for Cyprus. In N. Patsavos \& J. Pissourios (Eds.), The Cypriot city paradigm. Urbanity issues in design and planning (pp. 175-196). Athens: Domes.

Statistical Service. (2011). Population and social condition: Population census. Nicosia: Republic of Cyprus Ministry of Finance.

Troisi, J. (2013). "Ageing in place" in the Maltese islands. In J. Troisi \& H. Von Kontratowitz (Eds.), Ageing in the Mediterranean (pp. 273-294). Bristol: Policy Press.

Trudeau, D. (2018). Sustaining suburbia through new urbanism: Toward growing, green, and just suburbs? Urban Planning, 3(4), 50-60.

United Nations. (2018). Tracking progress towards inclusive, safe, resilient and sustainable cities and human 
settlements. New York, NY: Routledge.

Van Cauwenberg, J., De Donderd, L., Clarys, P., De Bourdeaudhuij, I., Buffel, T., De Witted, N., . . . Deforche, B. (2014). Relationships between the perceived neighborhood social environment and walking for transportation among older adults. Social Science \& Medicine, 104, 23-30.

Van Holle, V., Van Cauwenberg, J., Van Dyck, D., Deforche, B., Van de Weghe, N., \& De Bourdeaudhuij, I. (2014). Relationship between neighborhood walkability and older adults' physical activity: Results from the Belgian environmental physical activity study in seniors (BEPAS Seniors). International Journal of Behavioral Nutrition and Physical Activity. https://doi. org/10.1186/s12966-014-0110-3

Zeitler, E., Buys, L., Aird, R., \& Miller, E. (2012). Mobility and active ageing in suburban environments: Findings from in-depth interviews and person-based GPS tracking. Current Gerontology and Geriatrics Research, 3, 257186.

Zeitler, E., \& Buys, L. (2014). Mobility and out-of-home activities of older people living in suburban environments: 'Because I'm a driver, I don't have a problem'. Ageing \& Society, 35(4), 785-808.

\section{About the Author}

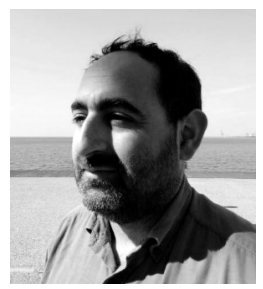

Byron loannou teaches Planning, Urban Design and Sustainable Built Environment at Frederick University and the Open University of Cyprus. He studied Architecture (Dip. Eng.) and Urban and Regional Planning (MSc and PhD) at the National Technical University of Athens. He has also studied Planning Law (PG Cert.) at Leeds Beckett University. During his early career, he worked as a teaching and research staff in Greek Universities, being also a visiting scholar in institutions worldwide. He has both professional and research experience in planning, urban design and development issues. His current research focuses on the environmental aspects of planning, density and sprawl, public space and urban green, planning law and inclusive urban development. He coordinates the Urban Planning and Development Unit at Frederick University (www.frederick.ac.cy/updu). 